\title{
COMPLICAŢIE NEUROLOGICĂ SEVERĂ LA O TÂNĂRĂ CU INFECŢIE HIV
}

\author{
Irina Ianache ${ }^{1}$, Cristiana Oprea ${ }^{1,2}$

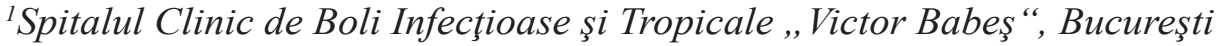 \\ 2 "Universitatea de Medicină şi Farmacie „, Carol Davila“, Bucureşti
}

\begin{abstract}
Introducere: Managementul pacienţilor cu infecţie HIV şi sindrom inflamator de reconstituţie imună (IRIS) reprezintă încă o provocare, în special la pacienţii cu infecţii oportuniste cerebrale.

Prezentare de caz: Prezentăm cazul unei tinere în vârstă de 26 de ani, diagnosticată cu infecție HIV într-un serviciu de hematologie şi internată în clinică noastră cu anemie severă, anxietate şi depresie. Probele biologice la internare au evidenţiat o anemie importantă, imunodepresie severă $\left(C D 4+63 / \mathrm{mm}^{3}\right)$ şi o viremie HIV crescută $\left(6,25 \log _{10}\right.$ copii/mL). După o lună de la iniţierea terapiei antiretrovirale cu schemă lamivudina 3TC, tenofovir (TDF) şi raltegravir (RAL), s-a observat o creştere importantă a imunităţii celulare (limfocite CD4+ $192 / \mathrm{mm}^{3}$ ) şi o scădere semnificativă a încărcăturii virale HIV la $1.5 \log _{10}$ copii/mL. Evoluţia clinică a fost dificilă, pacienta prezentând multiple episoade de convulsii tonico-clonice generalizate, halucinaţii auditive şi instalând hemipareză dreaptă. Examenul LCR a evidenţiat 2 celule/mmc, proteinorahie normală $(0,42$ g/l), ARN- HIV de $82 \mathrm{copii} / \mathrm{mL}$ iar culturile bacteriene şi fungice nu au fost crescute. Examenul IRM cerebral a evidenţiat leziuni hiperintense în secvenţele T2 şi FLAIR, hipointense în T1, localizate în ariile fronto-temporale, în emisferul cerebelos drept şi în punte. Deşi PCR ADN-JC a fost pozitiv în LCR, sugerând diagnosticul de leucoencefalopatie multifocală progresivă (PML), aspectul neuro-imagistic atipic şi simptomatologia psihiatrică asociată au făcut iniţial dificilă stabilirea diagnosticului. Starea generală s-a agravat treptat în special prin accentuarea simptomatologiei psihiatrice şi neurologice (tremor sever, hipotonie axială, slăbiciune musculară generalizată, insomnie şi anxietate marcată). Progresia semnificativă a leziunilor în substanţa albă subcorticală cu priză de contrast, în contextul ameliorării statusului imunologic, a scăderii importante a viremiei HIV şi a prezenţei ADN-JC în LCR, au orientat diagnosticul spre IRIS-PML. Pacienta a primit corticoterapie în doze mari, tratament antipsihotic şi a continuat terapia antiretrovirală, cu evoluţie clinică treptat favorabilă, cu ameliorarea treptată a simptomatologiei neuropsihice.

Concluzii: Diagnosticul afecţiunii neurologice a fost dificil în special din cauza debutului atipic, a prezenţei concomitente a simptomelor psihice şi a aspectului neuro-imagistic necaracteristic.
\end{abstract}

Cuvinte cheie: infecţie HIV, manifestări psihice, IRIS PML

\section{INTRODUCERE}

Leucoencefalopatia multifocală progresivă (PML) este o infecție oportunistă severă a sistemului nervos central (SNC), determinată de virusul JC și care afectează pacienții cu imunodepresie severă, în special pe cei cu infecție HIV $(1,2)$. PML se caracterizează printr-un proces de demielinizare a substanței cerebrale, cu infecția litică a oligodendrocitelor (3) și este considerată a fi una din cele mai frecvente cauze de mortalitate la pacienții cu infecție HIV și afectare neurologică (4). Deși nu există un tratament etiologic eficient pentru PML, s-a demonstrat că aproximativ jumătate dintre pacienții cu recuperare imunologică sub tratament antiretroviral (ARV) au prezentat și stabilizarea leziunilor cerebrale și a deficitelor neurologice $(5,6)$.

Incidenţa PML a scăzut în era terapiei antiretrovirale (ARV) în paralel cu creșterea semnificativă a ratei de supraviețuire. Cu toate acestea, 
în primele 6 luni după inițierea TARV (3, 7-9), aproximativ jumătate dintre pacienți pot avea o evoluție letală.

De asemenea, sindromul inflamator de reconstrucție imunologică (IRIS) reprezintă o adevărată provocare în managementul pacienților infectați HIV, caracterizându-se printr-o agravare paradoxală a manifestărilor clinice după inițierea terapiei ARV (2), estimându-se că aproximativ 1/3 din pacienții diagnosticați cu PML pot dezvolta IRIS (9-11).

\section{PREZENTARE DE CAZ}

Prezentăm cazul unei tinere de 26 de ani care a fost diagnosticată cu infecție HIV și anemie severă într-o clinică de hematologie și a fost transferată în clinica noastră în luna iunie 2015.

Pacienta nu avea antecedente personale semnificative, cu excepția unei keratite herpetice și a unor episoade recurente de herpes genital.

Examenul clinic la internare a evidențiat o pacientă palidă, cu tulburări de dispoziție, anxietate și depresie. Investigațiile de laborator au arătat anemie severă (Hb 6,7 g\%) și trombocitopenie moderată, imunodepresie severă (limfocite CD4+63/ $\mathrm{mm}^{3}$ ) și viremie HIV plasmatică crescută $\left(6,25 \log _{10}\right.$ copii/mL).

După corectarea anemiei, s-a iniţiat tratamentul antiretroviral cu lamivudină + tenofovir + darunavir/ritonavir, schemă care din cauza intoleranței digestive și a apariției unei erupții cutanate a fost modificată după 10 zile prin înlocuirea inhibitorului de protează (darunavir/ ritonavir) cu un inhibitor de integrază (raltegravir). Evaluarea imunității celulare după o lună de la inițierea terapiei ARV a evidențiat o creștere importantă a limfocitelor CD4+ la 192/ $\mathrm{mm}^{3}$ și o scădere semnificativă a viremiei HIV în plasmă (la 1,5 $\log _{10}$ copii/mL).

La sfârșitul lunii iulie, după 45 de zile de terapie $A R V$, pacienta a revenit în clinica noastră cu anxietate severă, halucinații auditive, crize convulsive parțiale cu generalizare secundară, tulburări de mers, slăbiciune musculară la nivelul hemicorpului drept și ataxie. Deficitul

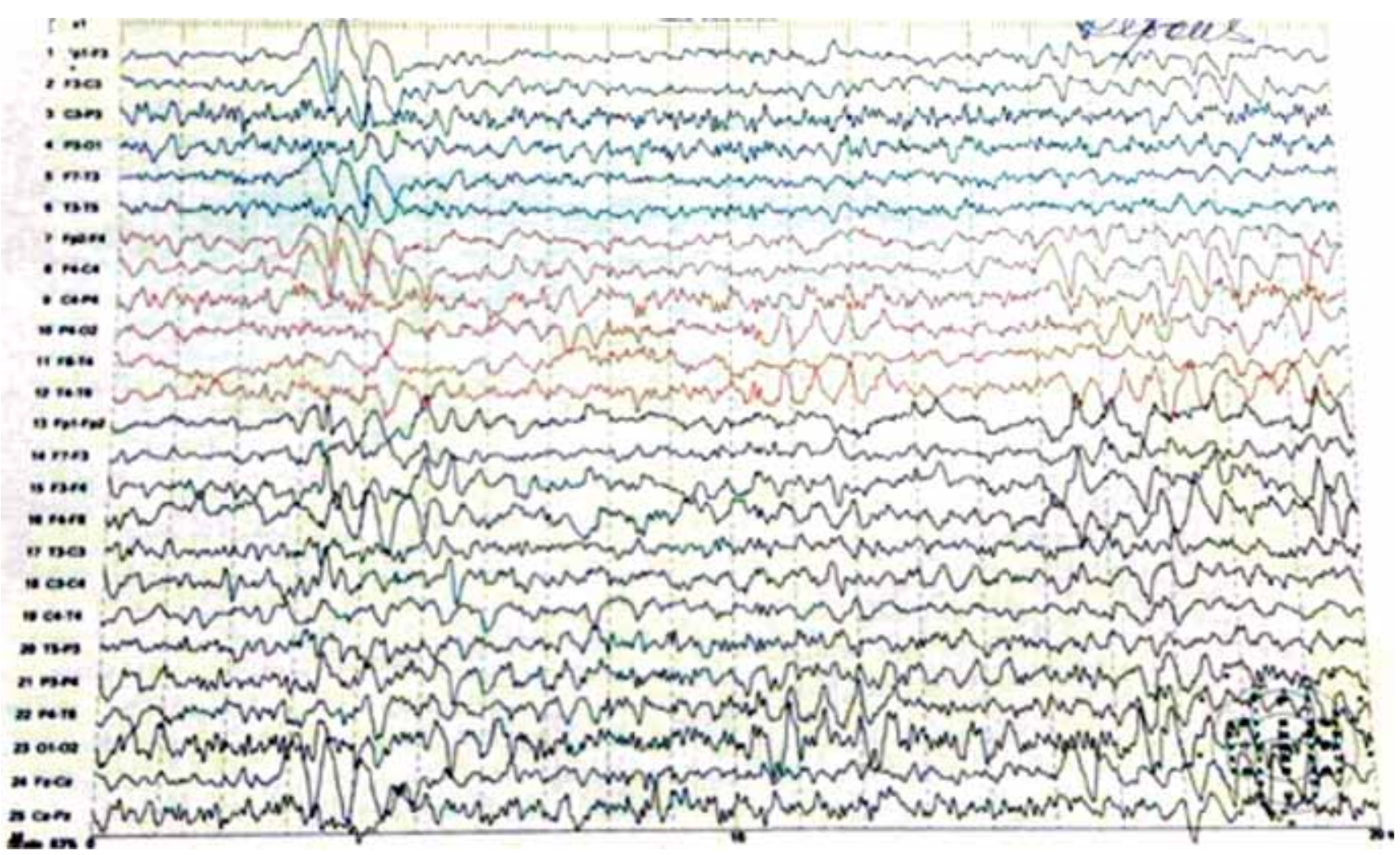

FIGURA 1. Traseu EEG cu unde delta frontale ascuţite 


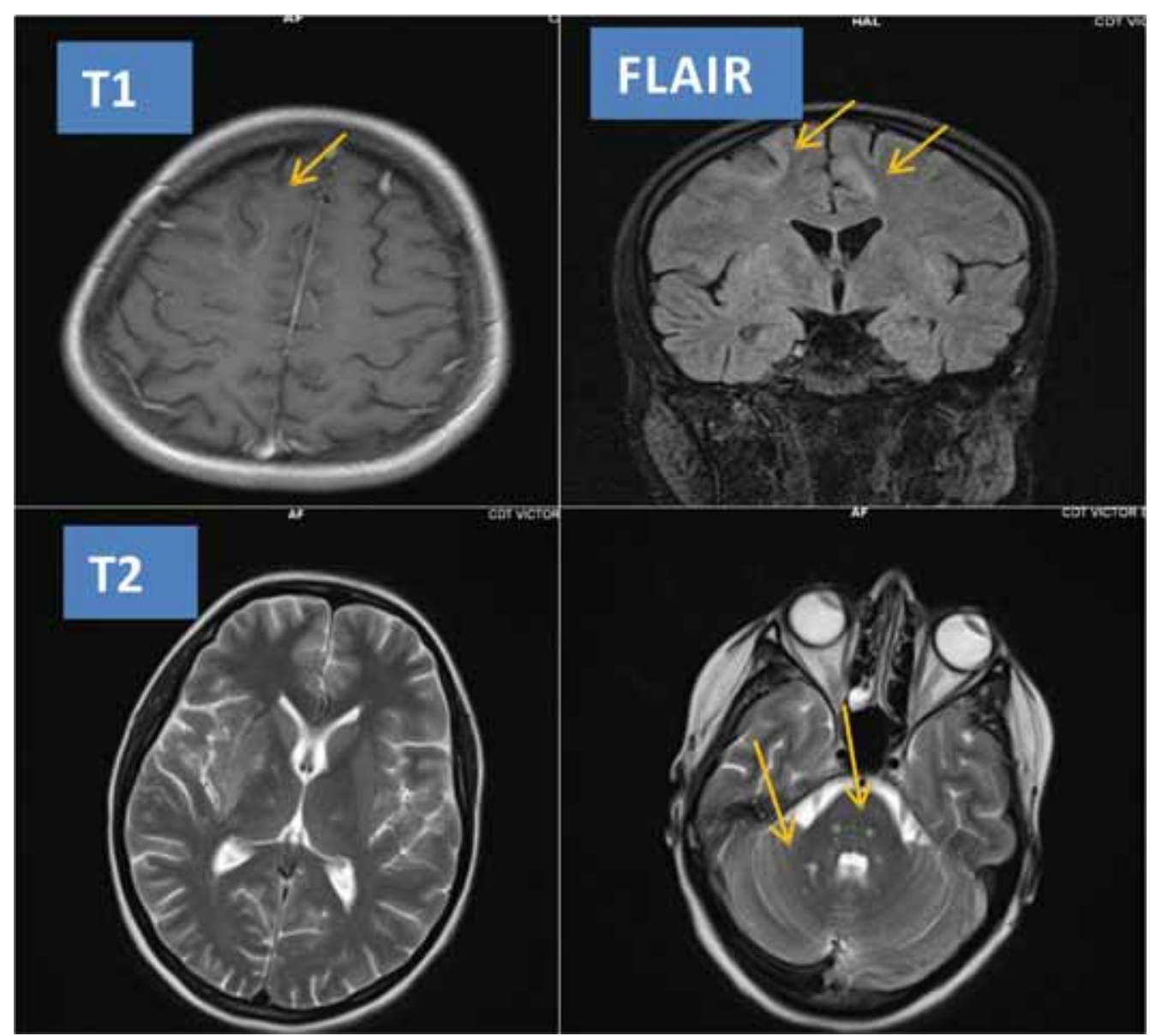

FIGURA 2. Examen IRM cerebral la internare evidenţiază leziuni hiperintense localizate în secvenţele T2 şi FLAIR, hipointense în T1 la nivelul emisferului cerebelos drept şi în punte

neurologic a evoluat progresiv, instalându-se hemipareză dreapta și parestezii la același nivel.

Examenul LCR a fost normal, cu frotiuri și culturi negative pentru bacterii, fungi sau virusuri și încărcătură virală HIV detectabilă $\left(1,9 \log _{10}\right.$ copii/mL).

Examenul EEG a evidențiat unde Delta frontale ascuțite (Fig. 1).

Prima evaluare neuroimagistică a evidențiat leziuni hiperintense în secvențele T2 și FLAIR și hipointense în T1, cu diametrul maxim de $3 \mathrm{~mm}$, localizate în emisferul cerebelos drept și simetric în punte. Modificări similare de semnal s-au decelat și în regiunea supratentorială, cu afectarea importantă a ariilor corticale și subcorticale, regiunile temporală și insulară dreapta fiind afectate mai mult comparativ cu zona insulară stânga, cu expansiune în lobul frontal, predominant pe partea dreapta. Modificările de semnal implicau și fibrele subcorticale în „U“, cu hipersemnal în secvență FLAIR. Aceleași modificări de semnal au fost descrise și paramedian, în regiunea corticală și subcorticală din lobul frontal. Toate aceste leziuni descrise nu captau priză de contrast, cu excepția unei mici zone la periferia leziunilor frontale drepte (Fig. 2).

Stabilirea diagnosticului neurologic a fost dificilă din cauza simptomatologiei clinice necaracteristice, a probelor biologice LCR inițial neconcludente și aspectului neuro-imagistic atipic.

Ținând cont de aspectul clinic și neuro-imagistic, s-au luat în considerare două entități clinice majore: encefalită virală (HSV, CMV) sau leziuni atipice de leucoencefalopatie multifocală progresivă. Deoarece pacienta prezentase în antecedente episoade herpetice repetate, avea un tablou clinic care asocia crize convulsive, deficit motor și simptome psihiatrice, posibil secunda- 
re afectării lobului temporal și imagini IRM cu hiperintensitate T2 și FLAIR în regiunea frontotemporală, s-a ridicat inițial suspiciunea unei encefalite herpetice. Absența leziunilor cingulare și a unui delir haotic, frecvent descrise în acest tip de encefalite și serologia HSV negativă au fost argumente împotriva acestui diagnostic. Deoarece etiologia herpetică a leziunilor cerebrale nu a putut fi exclusă de la prezentare, pacienta a primit inițial și tratament cu aciclovir injectabil (10 zile), corticoterapie, la care s-a asociat și tratament anticonvulsivant cu valproat de sodiu. Sub acest tratament s-a observat o discretă ameliorare a simptomatologiei neurologice, dar cu persistența și chiar agravarea simptomelor psihiatrice (anxietate severă, depresie și insomnie). Ulterior etiologia herpetică a leziunilor cerebrale a fost exclusă și de testele PCR negative în LCR pentru ADN-HSV.

Encefalită CMV a fost exclusă datorită aspectul neuro-imagistic necaracteristic (frecvent descris ca leziuni hiperintense T2 în substanța albă, predominant periventricular) și PCR-ADN CMV negativ în LCR.

Debutul progresiv cu afebrilitate a deficitului neurologic focal a pus în discuție și diagnosticul

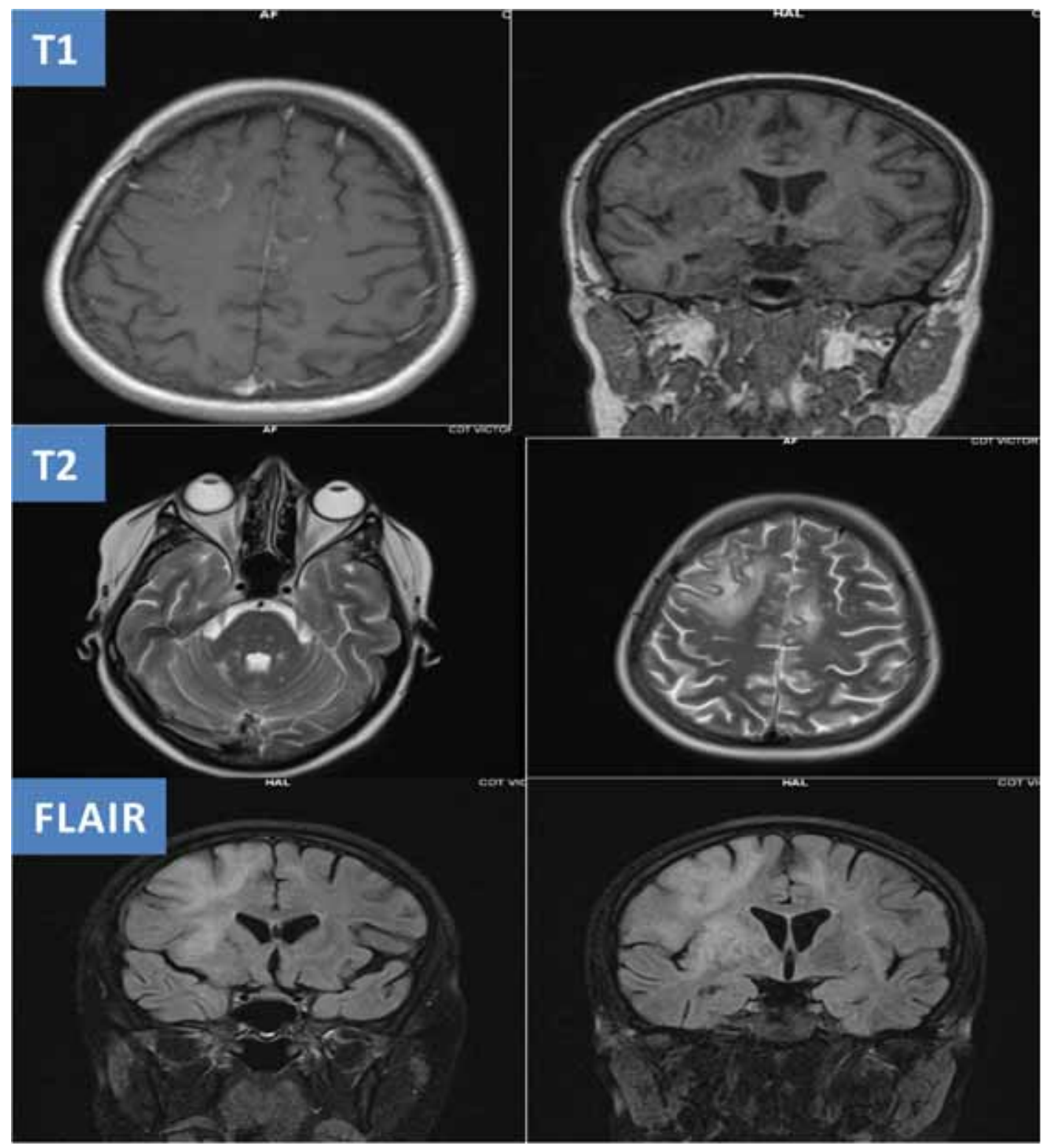

FIGURA 3. Examen IRM cerebral efectuat după 1 lună de tratament ARV arată extinderea leziunilor supratentoriale şi a leziunilor de la nivelul cerebelului cu extinderea prizei de contrast la nivelul ariilor frontale şi parietale. 
de leucoencefalopatie multifocală progresivă (PML), diagnostic care părea puțin probabil în prezența simptomelor de encefalită și a imaginilor IRM cerebral necaracteristice pentru această afectiune.

Evaluarea neuro-imagistică, după o lună de la inițierea terapiei ARV, a evidențiat o evoluție progresivă, cu creșterea în dimensiuni a leziunilor supratentoriale, modificări de semnal accentuate și o tendința semnificativă de confluare, mai ales în regiunea frontală, temporală și insulară pe partea dreaptă. Pe secțiunea axială T2 și coronară FLAIR s-au decelat multiple leziuni asimetrice, hiperintense cu extindere predominant în substanța albă subcorticală din emisferul cerebral drept, corona radiată stânga și aria frontală stânga paramediană. Pe secvența T1 s-a descris o leziune profundă subcorticală hipointensă ce asocia atrofie progresivă și tendința de cavitație, regiunile adiacente fiind hiperintense în secvență FLAIR. La nivelul cerebelos s-a observat o creștere în dimensiuni a leziunilor și a apărut o extindere a prizei de contrast de la nivelul leziunilor din ariile frontale și parietale bilateral (Fig. 3).

Examenul IRM cerebral efectuat după 2 luni de tratament ARV, în octombrie 2015, a evidențiat progresia continuă a leziunilor, atât la nivelul emisferelor cerebrale, cât și cerebeloase, cu edem masiv și efect de masă la nivelul ventriculului lateral drept cu priză de contrast importantă (Fig. 4).

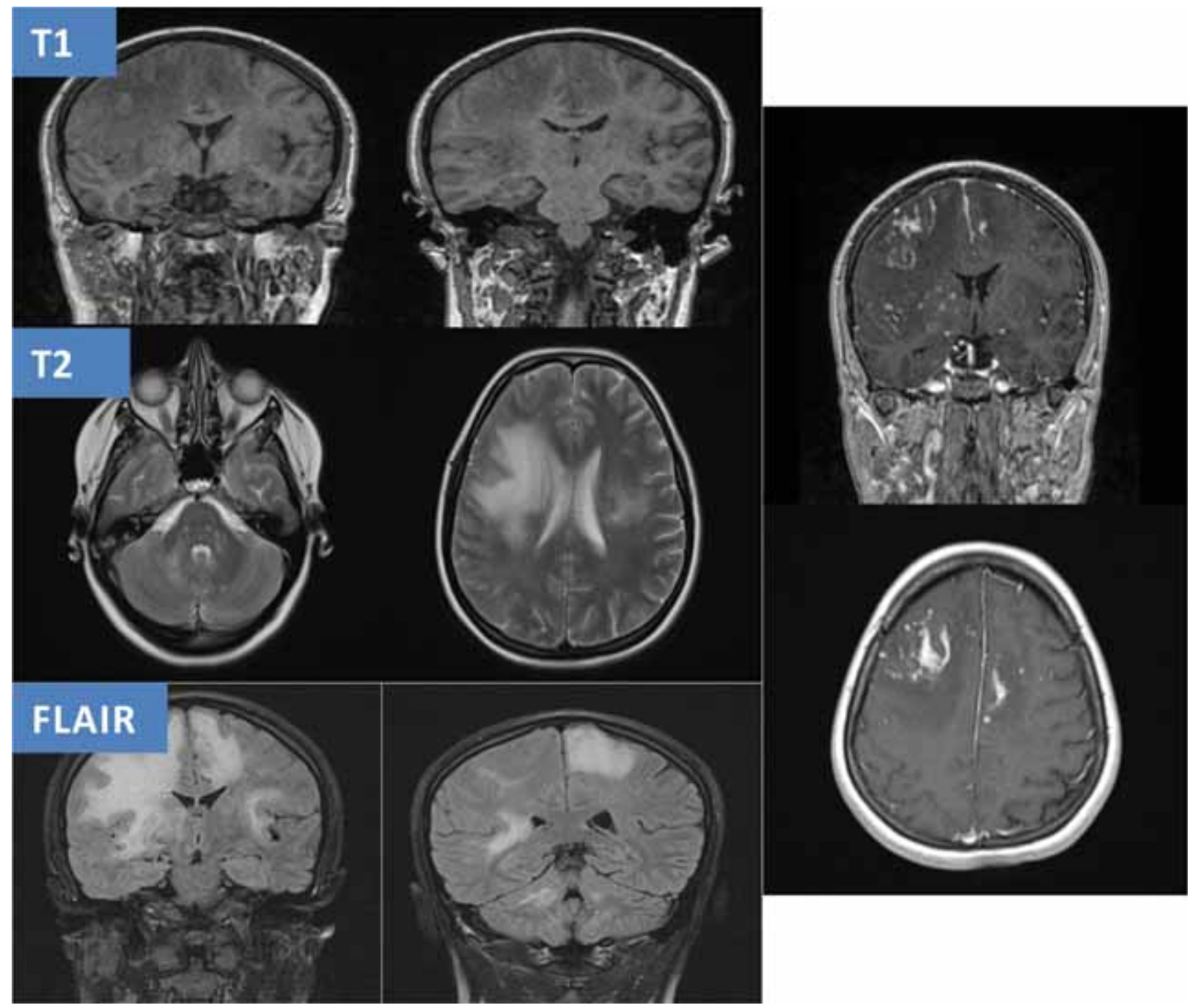

FIGURA 4. Examen IRM cerebral efectuat după 2 luni de tratament ARV: evoluţie progresivă a leziunilor infra şi supratentoriale cu edem masiv şi efect de masă pe ventriculul lateral asociind şi priză de contrast importantă. 
În condițiile progresiei leziunilor și a extinderii prizei de contrast, s-a inițiat corticoterapia în doze mari, fără a se întrerupe medicația antiretrovirală.

Evoluția progresivă a leziunilor cerebrale și rezultatul pozitiv pentru PCR-ADN JCV în LCR au făcut dificilă diferențierea între o formă clasică de PML și IRIS-PML. Argumente împotriva unei forme clasice de PML au fost aspectul neuro-imagistic necaracteristic și asocierea semnelor clinice de encefalită. Un argument important pentru diagnosticul de IRIS-PML a fost reprezentat de evoluția leziunilor cerebrale, cu extinderea în substanță albă, efect de masă pe ventriculul lateral și priză de contrast, în contextul ameliorării imunologice și scăderii rapide cu peste $2 \log _{10}$ a viremiei HIV în plasmă, precum și de creșterea semnificativă a numărului de limfocite CD8 circulante în periferie. Un alt argument clinic ar fost faptul că pacienta a prezentat o agravare importantă a stării clinice în primele luni de la inițierea tratamentului ARV, având totuși un răspuns favorabil (deși lent) după introducerea corticoterapiei în doze mari.

Simptomele psihiatrice asociate au ridicat de asemenea probleme de diagnostic, putând fi explicate atât în contextul afecțiunii neurologice, dar și ca o patologie psihiatrică de sine stătătoare.

După 4 luni de tratament ARV, psihiatric, anticonvulsivant și corticoterapie, s-a observat o ameliorare netă a evoluției clinice, cu remisiunea deficitelor neurologice și a simptomelor psihiatrice, persistând doar un tremor discret la nivelul membrului superior drept.

Evaluarea neuro-imagistică efectuată în noiembrie 2015, după 4 luni de corticoterapie și tratament ARV a evidențiat remisiunea semnificativă a leziunilor cerebrale, dispariția

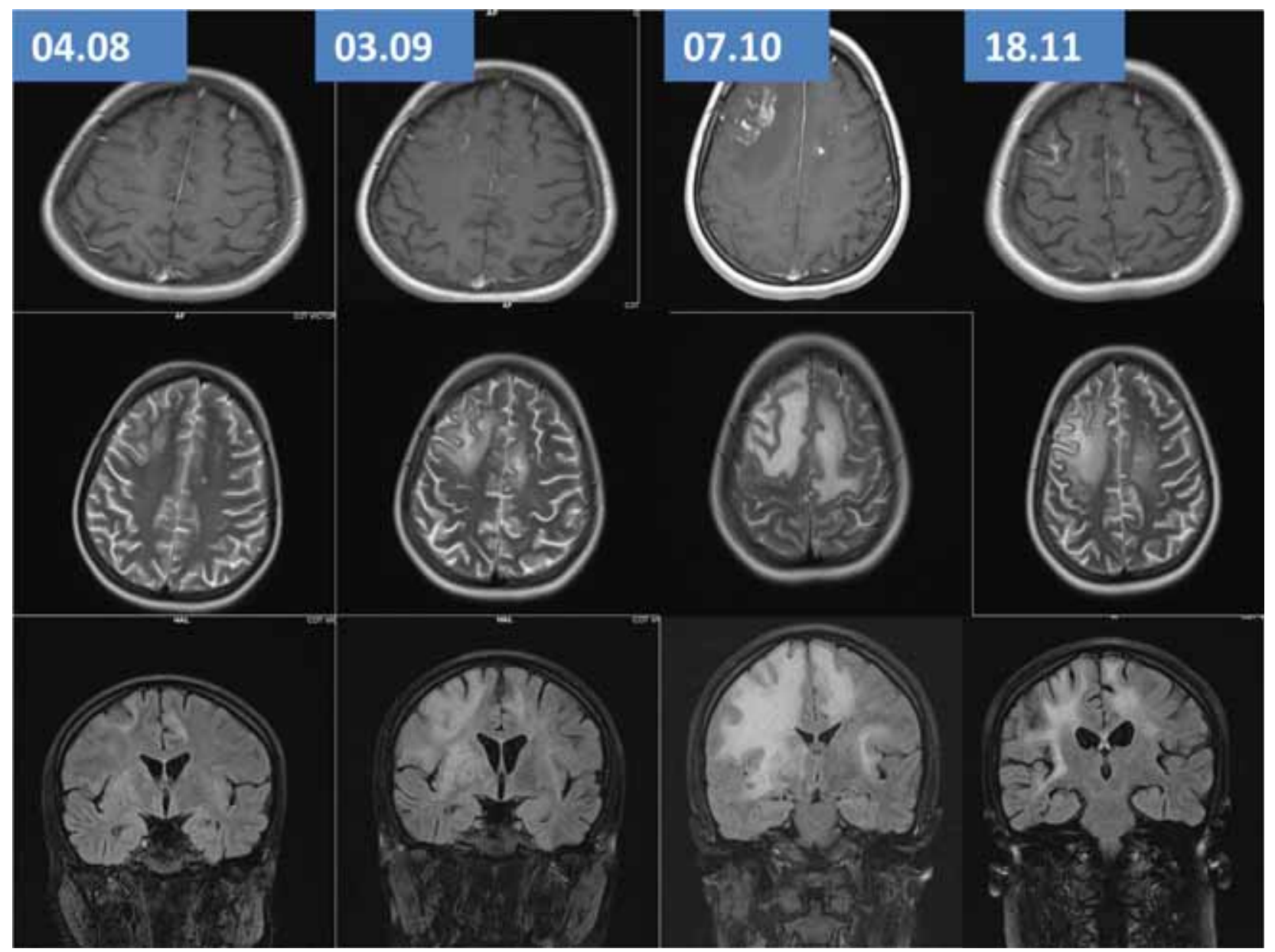

FIGURA 5. Evoluţia în dinamică a IRM. Se observă o remisiune importantă a leziunilor cerebrale după 4 luni de corticoterapie şi tratament antiretroviral 
edemului, a prizei de contrast și a efectului de masă pe ventriculii laterali (Fig. 5). Ultima evaluare imunologică efectuată în noiembrie 2016 a evidențiat un status imunologic bun (limfocite CD4+564/ $\mathrm{mm}^{3}$ ) și viremie HIV nedetectabilă.

\section{DISCUŢII}

Am prezentat un caz particular HIV și IRIS PML, la o pacientă cu debut clinic atipic, cu simptome psihiatrice importante asociate deficitelor neurologice și aspect neuroimagistic necaracteristic.

Deoarece simptomatologia neurologică s-a instalat după inițierea tratamentului antiretroviral, iar deteriorarea clinică a fost asociată cu refacerea statusului imunologic și scăderea importantă a viremiei HIV în plasmă, acestea au fost argumente pentru un IRIS-PML „prin demascare“. În literatura de specialitate această patologie este descrisă ca fiind o deteriorare neurologică nou apărută la un pacient cu HIV și imunodepresie severă și care apare în general între 3 săptămâni și 3 luni de la inițierea tratamentului ARV (2, 12-14).

Un număr relativ mare de studii au sugerat că la pacienții care dezvoltă IRIS PML „prin demascare“, există o afectarea frecventă la nivelul cerebelului, cu leziuni doar la nivel infratentorial sau în asociere cu leziuni supratentoriale. Au fost propuse mai multe teorii pentru a explica acest „pattern“, incluzând infecția la nivelului stratului intern granular al neuronilor din cerebel, fără afectarea oligodendrocitelor, sau un răspuns imunologic întârziat în această arie comparativ cu alte regiuni cerebrale. La pacienții cu infecție HIV, acest tropism particular al virusului JC se asociază frecvent cu atrofie cerebrală (19-21). Pacienta a prezentat leziuni demielinizante cu evoluție progresivă și priză de contrast la nivelul cerebelului, și al trunchiului cerebral dar și la nivel supratentorial.

Rata de supraviețuire a fost frecvent asociată cu captarea prizei de contrast pe imaginile IRM cerebral, studiile din literatura de specialitate sugerând că ar exista o asociere între intensitatea contrastului și severitatea inflamației sau localizarea leziunilor $(9,15,22)$. Se consideră de asemenea că pacienții cu IRIS-PML „prin demascare" ar avea o rată de supraviețuire mai mare comparativ cu cei ce dezvoltă IRIS PML „paradoxal“, aceștia din urmă prezentând leziuni cerebrale cu diametre mai mari pe imaginile IRM și un debut mai rapid al simptomelor (2, 15). Captarea prizei de contrast și tratamentul cu doze mari de corticosteroizi sunt consideraţi factori de prognostic favorabil. S-a observat de asemenea că mortalitatea este mai mare la pacienții diagnosticați cu IRIS-PML comparativ cu cei cu forme clasice de PML cu evoluție progresivă (9). Cu toate că există doar studii limitate, se consideră că tratamentul ARV în asociere cu corticoterapia în doze mari reprezenta cea mai bună opțiune de tratament pentru pacienții cu IRIS-PML $(2,15,16)$.

O problemă dificilă de diagnostic în acest caz a fost reprezentată și de stabilirea cauzei simptomatologiei psihiatrice asociate, deoarece inițial nu a putut fi exclus un debut concomitent al unei afecțiuni psihiatrice organice sau posibilitatea apariției simptomelor psihiatrice în contextul leziunilor PML. Acest caz pare singular deoarece în literatură nu au fost descrise cazuri similare cu afectare psihiatrică secundară leziunilor de PML.

Prezența tulburărilor psihice concomitente a reprezentat o adevărată provocare pentru managementul afecțiunii neurologice la această pacientă cu infecție HIV și imunodepresie severă. 